\title{
The Animal Health Law-Regulation EU 2016/429 and the Future of Food Safety and Free Commerce in Europe
}

\author{
Giancarlo Ruffo, Valentina Locatelli, Francesco Maraschi and Paola Fossati \\ Department of Health, Animal Science and Food Safety, Universitàdegli Studi di Milano, via Celoria 12, Milano 20133, Italia
}

\begin{abstract}
The aim of this study was to analyze the contents of Reg. (EU) No. 429/2016, and to assess its role in guaranteeing the efficient application of the disease prevention and control rules into member state. Furthermore, the authors evaluated the impact of the abovementioned Regulation on the legislation on public health and food safety already in force in Europe (Regulations EC No. 178/2002, No. 882/2004, No. 853/2004) and considered the global impact of the new rules on the effective functioning of the internal market. The study pays attention also to the TFEU (treaty of lisbon on the functioning of the European union) procedure to delegate to the commission the power to adopt non-legislative acts of general application that supplement or amend certain non-essential elements of a legislative act.
\end{abstract}

Key words: Animal health law, food safety, veterinary official controls, EU Regulation, public health, transmissible animal diseases, disease notification.

\section{Introduction}

The authors analyze the Regulation (EU) No. 429/2016 on transmissible animal diseases and amending and repealing certain acts in the area of animal health ("Animal Health Law”), and assess it in the light of the European Food Safety Legislation already in force. The study regards the subject matter and aim of the Regulation, focusing on "key" acts: transmissible disease listing and categorysation, disease notification, disease prevention and control rules, including disease notification, reporting, surveillance, eradication.

\section{Methodology}

The authors analyze the following legislation:

- Regulation (EU) No. 429/2016, “Animal Health Law" [1];

- Treaty of Lisbon-TFEU (treaty of lisbon on the functioning of the European union), 2009 [2];

- Regulation (EC) No. 178/2002 laying down the

Corresponding Author: Paola Fossati, DVM, assistant professor of animal law, research fields: animal ethics and veterinary forensic medicine. general principles and requirements of food law [3];

- Regulation (EC) No. 882/2004 official controls on feed and food law, animal health and animal welfare rules [4];

- Regulation (EC) No. 853/2004 laying down specific hygiene rules for food of animal origin [5].

The Regulation (EU) No. 429/2016 considers the links between animal health and public health, the environment, food and feed safety, animal welfare, food security, together with economic, social and cultural aspects [1]. The animal health measures provided in this Regulation are taken on the basis of the risk assessment and of the available scientific evidence; in this last regard, the work of the EFSA (European Food Safety Authority) is very important $[3,6]$.

In order to ensure the correct and harmonized application of the Regulation (EU) No. 429/2016, and to ensure the same animal health status in all member states, the European legislator has established a list of transmissible animal diseases, which pose a risk to animal or public health in the union (Article 5 and Annex II), and has delegated to the commission the power to adopt acts amending the Annex II (Articles 6, 
7) $[1,8,10,11]$.

The listings provided in Article 5 and in Annex II to
Regulation (EU) No. 429/2016 contain the following diseases (Table I):

Table I listings of diseases.

\begin{tabular}{|c|c|c|c|c|}
\hline \multicolumn{5}{|l|}{ Art. 5} \\
\hline Foot and mouth disease & Classical swine fever & African swine fever & $\begin{array}{l}\text { Highly pathogenic } \\
\text { avian influenza }\end{array}$ & African horse sickness \\
\hline \multicolumn{5}{|l|}{ ANNEX II } \\
\hline $\begin{array}{l}\text { Rinderpest } \\
\text { (cattle plague) }\end{array}$ & Sheep and goat plague & Swine vesicular disease & Bluetongue & Teschen disease \\
\hline Sheep pox or goat pox & Rift Valley fever & Lumpy skin disease & Vesicular stomatitis & $\begin{array}{l}\text { Venezuelan equine viral } \\
\text { encephalomyelitis }\end{array}$ \\
\hline Hemorrhagic disease of deer & $\begin{array}{l}\text { Contagious bovine } \\
\text { pleuropneumonia }\end{array}$ & Newcastle disease & Bovine tuberculosis & $\begin{array}{l}\text { Bovine brucellosis (B. } \\
\text { abortus) }\end{array}$ \\
\hline $\begin{array}{l}\text { Ovine and caprine } \\
\text { brucellosis } \\
\text { (B. melitensis) }\end{array}$ & Anthrax & Rabies & Echinococcosis & $\begin{array}{l}\text { Transmissible } \\
\text { spongiform } \\
\text { encephalopathies } \\
\text { (TSE) } \\
\end{array}$ \\
\hline Campylobacteriosis & Listeriosis & \begin{tabular}{|l|}
$\begin{array}{l}\text { Salmonellosis (zoonotic } \\
\text { salmonella) }\end{array}$ \\
\end{tabular} & Trichinellosis & Verotoxigenic E. coli \\
\hline $\begin{array}{l}\text { Viral haemorrhagic } \\
\text { septicæmia (VHS) }\end{array}$ & $\begin{array}{l}\text { Infectious hematopoietic } \\
\text { necrosis (IHN) }\end{array}$ & $\begin{array}{l}\text { Epizootic hematopoietic } \\
\text { necrosis in fish (EHN) }\end{array}$ & $\begin{array}{l}\text { Epizootic ulcerative } \\
\text { syndrome in fish } \\
\text { (EUS) }\end{array}$ & $\begin{array}{l}\text { Infection with } \\
\text { Bonamiaexitiosa }\end{array}$ \\
\hline $\begin{array}{l}\text { Infection with Perkinsus } \\
\text { marinus }\end{array}$ & $\begin{array}{l}\text { Infection with } \\
\text { Microcytosmackini }\end{array}$ & $\begin{array}{l}\text { Taura syndrome in } \\
\text { crustaceans }\end{array}$ & $\begin{array}{l}\text { Yellowhead disease in } \\
\text { crustaceans }\end{array}$ & $\begin{array}{l}\text { Koi herpes virus disease } \\
(\mathrm{KHV})\end{array}$ \\
\hline $\begin{array}{l}\text { Infectious salmon anaemia } \\
\text { (ISA) }\end{array}$ & $\begin{array}{l}\text { Infection with Marteilia } \\
\text { refringens }\end{array}$ & $\begin{array}{l}\text { Infection with Bonamia } \\
\text { ostreae }\end{array}$ & $\begin{array}{l}\text { White spot disease in } \\
\text { crustaceans }\end{array}$ & \\
\hline
\end{tabular}

A disease is considered to be an "emerging disease" when it is not yet included in listing diseases provided for in Article 5.

The Article 18 regulates the animal disease notification. Disease notification is compulsory for several cases. When there are any reasons to suspect the presence in animals of a listed disease (Article 5), or where the presence of such a disease is detected in animals, the operators immediately notify the competent authority $[1,7,9,11]$. Those diseases do not normally occur in the union and for their immediate eradication, specific measures must be taken (point (a) of Article 9 (1)) [1, 7].

When there are any reasons to suspect the presence in animals of a listed disease for which there is a need for surveillance within the European union, or where the presence of such a disease is detected in animals, the operators notify the competent authority of the appearance of the disease as soon as practicable (point (e) of Article 9 (1)) [1, 7].

Notification within member states: when there are the presence of abnormal mortalities and other signs of serious disease or significant decreased production rates with an undetermined cause, the operators notify a veterinarian of them; he or she shall carry out further investigation, including sampling for laboratory examination [1].

The member state may decide that the notifications provided for in late point may be directed to the competent authority [1].

The commission shall adopt rules to prevent and to control disease, with regard to risk assessment and seriousness of disease [2, 3].

The Reg. (EU) No. 429/2016 lays down that the commission shall adopt delegated acts or implementing acts (Articles 291 and 290 of the TFEU), respecting the requirements provided for by the same Regulation [1, 2].

The Article 270 of Reg. (EU) No. 429/2016 repeals a lot of decisions, directives and only a few regulations (No. 1760/2000), with the goal to ensure the correct application of legislation on veterinary and 
zootechnical matters[1, 10].

\section{Results and Discussion}

The EU has experienced in 1994 the health emergency with Bovine spongiform encephalopathy (BSE) [8, 10, 11]. This experience has led the European legislator to use the instrument of the Regulation in order to harmonize legal behavior at EU level, aiming to ensure high standards of human health and a functioning internal market, with regard to trade in live animals and foods from animal origin [8, 10, $11]$.

The Reg. (EC) No. 178/2002, was born in a time of emergency; it represented the foundation of food law and declared the principles of food safety in all countries of the European union and also with reference to third countries (import/export). With Reg. (EC) No. 178/200, the union governed directly food safety, and it gave power to member states [3, 11].

However the Legislation on food safety was missing an essential and primary aspect, which is the harmonization of animal health, together with the uniformity of measures in cases of infectious diseases that had repercussions on human health $[4-6,8,10$, $11]$.

Animal health was regulated so messy, confusing and not harmonized, divided between directives and decisions, and animal health rules of the individual member states, which, depending on the internal health problems, autonomously decided which infectious diseases should be notifiable and which were the restrictive health measures on animal movements $[8,10,11]$.

\section{Conclusions}

Like the Reg. (EC) No. 178/2002 on food safety, the new Reg. (EU) No. 429/2016 represents a starting basis for future legislation or acts on the protection of animal health [1, 3].

The list of notifiable diseases provided for by Reg. (EU) No. 429/2016 has the effect of indirectly but immediately modifying all the lists of infectious diseases contained in the existing European directives and decisions, and also the laws of member states on the same issue $[1,7,9-11]$, with the aim to address uniform conditions for the health status of animals in the European union, and to make sure that the EU internal market will be safe and so will be the trade in live animals, while avoiding movement restrictions imposed by the national veterinary laws of single member states [3, 4, 7, 9].

Reg. (EU) No. 429/2016, which shall apply from 21 April 2021, will impact on EU animal health legislation, because it will supplement existing provisions on food safety, even with regard to the management of bio-security in animal breeding and derived products.

According to this regulation, animal health will no longer be governed by individual member states but the European union itself will directly order measures to fight against transmissible diseases of animals.

\section{References}

[1] Regulation (EU) 2016/429 of the European Parliament and of the Council of 9 March 2016 on Transmissible Animal Diseases and Amending and Repealing Certain Acts in the Area of Animal Health ("Animal Health Law").

[2] Treaty of Lisbon on the Functioning of the European Union (TFEU), 2009.

[3] Regulation (EC) No. 178/2002 of the European Parliament and of the Council of 28 January 2002 Laying down the General Principles and Requirements of Food Law, Establishing the European Food Safety Authority and Laying down Procedures in Matters of Food Safety.

[4] Regulation (EC) No. 882/2004 Official Controls on Feed and Food Law, Animal Health and Animal Welfare Rules.

[5] Regulation (EC) No. 853/2004 Laying down Specific Hygiene Rules for Food of Animal Origin.

[6] Regulation (EU) No. 182/2011 of the European Parliament and of the Council of 16 February 2011, Laying down the Rules and General Principles Concerning Mechanisms for Control by Member States of the Commission's Exercise of Implementing Powers.

[7] Belloli, A. 2006. “The Local Health Authority.” In Guide to the Practice of Veterinary Medicine for Official 
Food Safety and Free Commerce in Europe

Veterinarian and Veterinary Practitioner. Turin, Italy: CGEMS, 121-44. (in Italian)

[8] Marabelli, R. 2006. "The International Veterinary Services." In Guide to the Practice of Veterinary Medicine for Official Veterinarian and Veterinary Practitioner. Turin, Italy: CGEMS, 19-34. (in Italian)

[9] Marabelli, R. 2006. “The Italian Ministry of Health.” In Guide to the Practice of Veterinary Medicine for Official Veterinarian and Veterinary Practitioner. Turin, Italy:
CGEMS, 36-50. (in Italian)

[10] Pezza, F., and Ruffo, G. 2006. "Role and Function of Veterinarian in the Area of Animal Health.” In Guide to the Practice of Veterinary Medicine for Official Veterinarian and Veterinary Practitioner. Turin, Italy: CGEMS, 157-223. (in Italian)

[11] Pezza, F., Ruffo, G., and Fossati, P. 2008. Veterinary Law and Legislation. Milan, Italy, Le Point Veterinaire Italie, 47-84, 113-69. (in Italian) 